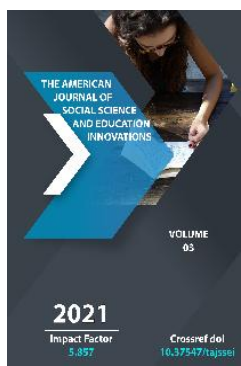

\title{
The Concept Of Civil Responsibility In Young People And Its Peculiarities
}

\author{
Turatov Shukhrat Bakhromovich \\ Jizzakh Polytechnic Institute " Social Department Of "Sciences" Teacher, Uzbekistan
}

Journal Website:

http://theamericanjour

nals.com/index.php/taj

ssei

Copyright: Original content from this work may be used under the terms of the creative commons attributes 4.0 licence.

\section{ABSTRACT}

The article analyzes the socio-philosophical importance of the formation of civil responsibility in young people in the process of building a democratic legal state and civil society of our country. At present, attention is paid to the issue of means and factors affecting the comprehensive formation of civil duty and responsibility in young people.

\section{KEYWORDS}

Citizenship, democracy, law, state, civil society, civil responsibility, position, legal literacy, entrepreneurship, youth, responsibility.

\section{INTRODUCTION}

The fact that citizens in our country have a good knowledge of their rights, duties and responsibilities is an important condition and factor of Social Development, great attention is paid to issues such as knowledge of laws, their observance, moral and aesthetic values, raising consciousness and culture, maintaining labor discipline in the life of society, 
conscientious approach to social duty, and in the current Civil responsibility in the social development of Uzbekistan characterizes the conscious attitude of citizens to the achievements and successes achieved in the democratic development of society.

Civil responsibility is an integral part of democratic changes in society, and society in its democratic development gives citizens different rights that translate equality, freedom, unity into life reality, while at the same time, observance of these rights requires the use of their rights creatively, in the case of the interests of society.

Today in Uzbekistan, in the process of restoration of a democratic legal state and civil society, a citizen will be able to take an active part in solving the problems of society in a state based on existing rights. Uzbekistan pays great attention to the issue of civil responsibility and formation of an active civil position of its citizens, creatively using the achievements of developed countries in the field of science, culture, statehood, law, politics, diplomacy and economic development. The issue of civil responsibility of the younger generation and the formation of an active civil position is a topical issue today. "Another important task we have is to consistently implement a print - out on the interdependence of mutual responsibility, rights and duties between citizens, the state and society," said the president of the Republic of Uzbekistan.Mirziyoyev, - this is a printsip is a constitutional framework that ensures effective cooperation between the state and the individual, state and civil society in solving important tasks facing our country. We are all equally responsible for the prosperity of our motherland - citizens, society and the state, for the strengthening of peace and stability in our country, for the preservation, enrichment of our historical, spiritual and cultural heritage and for the decoration of future generations. We must further strengthen our work in order to preserve and strengthen the atmosphere of friendship and harmony, mutual respect and solidarity between representatives of different nationalities and peoples living in our country. [1.36-37.]

At present, great attention is paid to the issue of increasing legal literacy of citizens, comprehensive development of medium and small entrepreneurship, formation and strengthening of a sense of responsibility and active civil position in youth in relation to society, independence. As noted by the first president of our country, if the child receives seventy percent of the information under the age of five, the importance of the family in the formation of the spirituality of the individual is manifested in the great. "Anyone who has a mind understands well that while there is life in this light, there is a family, there is a family, there is a so-called Priceless blessing, while there is a child, a person always lives with cherished dreams and aspirations. Today, all our work is carried out for the happiness of our children and their light future. But happiness is not determined only by wealth,wealth. A decent, educated and intelligent, hardworking, faith-loving child is the greatest wealth not only of parents, but of the whole society as a whole." [ 2.55-56.].

The formation of civil responsibility and active civil position in young people is carried out on the basis of strengthening ideological immunity on the basis of national selfawareness, restoration of historical memory, raising national pride and pride. The deep acquisition of the achievements of science by young people, the strong study of foreign languages, computer technologies, honest work, business and entrepreneurship, contribution to the economic, socio-political, 
spiritual and cultural development of Uzbekistan is of great importance in the process of formation and promotion of civil responsibility and active civil position of young people.

Society is restored with the help of citizens with a high level of civil consciousness and activity, civil responsibility. The responsibility of a citizen is a concept of a philosophical, legal, sociological and political essence that is used to understand the belonging of a citizen to a particular state, to express his duty and obligations before the state. The responsibility of a citizen includes the duty and sense of responsibility of a citizen to respect the state, the Constitution, state symbols, to protect the state system and the rule of law

President Of The Republic Of UzbekistanAs Mirziyoyev noted - "the result of the reforms carried out in our country today is directly related to the ranks of young cadres, who are above all, high-spiritually, independentminded, capable of taking responsibility for the fate and prospects of our homeland". [ 2. 24-25. ] In the state policy on youth, which is carried out today, the ideological immunity is formed in the spirit of ensuring the rights, freedoms and legitimate interests of young people, maintaining the life and health of young people, facilitating the spiritual, spiritual, physical and moral perfection of young people, ensuring open and quality education for young people, creating conditions for employment of young people and, great attention is paid to the issue of upbringing as a person whose firm confidence and views on life are decided. In the formation of civil responsibility and active civil position in young people, the issue of raising the level of legal awareness and legal culture of young people also plays an important role. IQT support and encouragement of talented and talented young people, creation of conditions for the development of youth entrepreneurship, formation of aspiration to a healthy lifestyle in young people, as well as the creation of conditions for the meaningful Organization of leisure of young people and mass development of youth sports, moral and material support of young families, the implementation of a system of, the development of cooperation with international organizations that carry out activities in the field of realization of the rights and freedoms of young people also plays an important role in the state's youth policy.

In ensuring the stability of our country, it will be important for the formation of civil responsibility and active civil position in young people who will deeply understand the essence and essence of the reforms carried out in the socio-political, economic, spiritual and cultural sphere, who are eager for the Steam and prospects of society, who live in the burning flame of glue and

At the same time with the national values and traditions that are being restored in the life of young people in ensuring the socio-political stability of the society at the present time, the emergence of the requirements for the rapid transformation of socio-political values that arise as a result of the penetration of foreign innovative changes and further deepening of reforms,

In ensuring the stability of Uzbekistan, education of self-sacrificing, patriotic young people who deeply understand the essence and essence of the reforms carried out in the socio-political, economic, spiritual and cultural sphere, who live in harmony with society for the sake of the present and the future, who live as glue and citizen, their ideological upbringing, raising the level of socio-political "By integrating the National idea into the hearts and minds of our compatriots, the 
formation of an ideological immune system in them is a periodical demand. This is not a process that takes place in one zone, one by one. Bunda requires activity, factorization of each person. And its implementation will increase the potential of Uzbekistan, help to restore the Great State of its future, strengthen the welfare of our people." [3. 28. ]

Youth is a large and active social layer of the population of Uzbekistan. The formation of active civil responsibility in young people is carried out on the basis of the formation in them of an independent mind, independent consciousness, independent perseverance, this determination is formed on the basis of their aspiration to life goals, is strengthened, expresses the duty and responsibility of parents, the land of elu, their people, LIFE, Nature, Society and Vatan, dinu e'tiqodi, arises from the Increasing social activity of young people, formation of civil responsibility in them is carried out on the basis of ideological work, integration of national idea and ideology into the minds and hearts of young people, strengthening ideological immunity.

In conclusion, it should be noted that the process of formation of civil responsibility among young people in Uzbekistan is carried out in harmony with the policy in the field of education of healthy and harmonious generation, the issues of youth's knowledge of different languages, perfect acquisition of computer equipment, mastering of new techniques, technology and science achievements, entrepreneurship and business activity are

The reforms carried out in Uzbekistan increase the role and importance of young people who are the most active, aspiring, business and entrepreneurial social strata in society.

\section{REFERENCES}

1. Mirziyoev Sh.M. Konstitusiya - erkin va farovon hayotimiz, mamlakatimizni yanada taraqqiy ettirishning mustahkam poydevoridir //xalqimizning roziligi bizning faoliyatimizga berilgan eng oliy Bahodir. 2-jild. Toshkent, O'zbekiston, 2018 yil, 36-37 betlar.

2. Karimov I.A. Yuksak ma'naviyat engilmas kuch. T. "Ma'naviyat", 2008, 5556-betlar.

3. Mirziyoev Sh.M. Konstitusiya - erkin va farovon hayotimiz, mamlakatimizni yanada taraqqiy ettirishning mustahkam poydevoridir //xalqimizning roziligi bizning faoliyatimizga berilgan eng oliy Bahodir. 2-jild. Toshkent, O'zbekiston, 2018 yil, 24-25 betlar.

4. Ergashev I. va boshqalar. O'zbekistonning mustaqil taraqqiyoti va mafkuraviy jarayonlar. Toshkent, ijod dunyosi, 2002 yil, 28 bet.

5. Saitqosimov A.I. Yoshlarning ijtimoiysiyosiy faolligini oshirish jamiyat barqarorligining muhim mezoni // "yoshlarga oid davlat siyosatini amalga oshirish strategiyasi: mavjud vaziyat va rivojlantirish istiqbollari" mavzusidagi ilmiy-amaliy konferentsiyasi maqolalar to'plami. Toshkent, 2019 yil, 192 bet. 